\title{
CPS Energy: Leading The Way To A Sustainable Future
}

Steven S. Ferrell, University of the Incarnate Word, USA

Ryan Lunsford, Ph.D., University of the Incarnate Word, USA

\begin{abstract}
As the production and distribution costs of energy continue to rise, end-consumers are increasingly realizing the impact on their pocketbook. Moreover, with these climbing monthly utility bills, the natural monopoly structure of the energy industry deserves examination to determine best-practices. The vast majority, a full $69 \%$ of utility companies in the United States are structured in the form of an investor-owned utility. The remaining $31 \%$ of energy companies are publicly-owned, either as cooperatives or as publicly-owned utilities accountable to the cities and municipalities that own them. This case study presents CPS Energy, the Nation's largest cityowned and publicly-operated energy company, which serves the Country's seventh largest City. CPS has provided natural gas and electric service for more than a half century to the 1.5 million Texans who call the Alamo City home. With its impressive record of reliability, customer service, financial integrity, renewable energy policies, progressive environmental policies, community relations, and, perhaps, most important to consumers, low rates, CPS is the model of what a sustainable, $21^{\text {st }}$ Century energy company can be.
\end{abstract}

Keywords: Energy Company; Utility; City-Owned; Publicly-Operated

\section{INTRODUCTION}

Q ocated deep in the heart of South Central Texas, San Antonio is all too familiar with record-breaking temperatures and intense sun that shines unrelenting heat in the lengthy summer. Cold snaps in the winter months coupled with extreme spikes in energy demand often results in property owners' utility bills that can be devastating to many fixed- and low-income residents (McKinzie, 2013). As any resident of San Antonio and the surrounding Hill Country can attest, heat is indeed abundant, intense, and relentless during the summer months while winter is often a rollercoaster ride of mild temperatures with the injection of cold snaps. As is common in many parts of the Country, energy costs are usually on the minds of the more than one million CPS Energy customers. Fortunately for the Alamo City, CPS proactively and relentlessly explores innovative options to manage costs and keep prices reasonable, resulting in customer-provider relationships that are usually amicable (Zaja, 2010). This aspect of CPS's relationship to its customer, and its relationship to the City of San Antonio itself, makes it an interesting case study. CPS provides a promising business model that is responsive to the needs of the municipality and serves as a model for other cities to adopt.

\section{BACKGROUND}

For nearly a century, public utilities have been accepted as legalized monopolies regulated by state agencies and operating on fixed profit margins (Audin, 2005). According to the UDI Index of power producers and distributers, there are 3,356 such monopolies in the United States with $69 \%$ of all power generated and distributed in this Country, generated and distributed by the largest of those investor-owned utilities (Giles \& Brown, 2013). Public electric utilities service approximately $14 \%$ of all electricity customers nationwide. Of the rest, $12 \%$ are serviced by rural electric associations and 5\% by power marketers (APPA, 2013). Granting legal monopolies to public utilities has historically been justified as being necessary to ensure affordable and reliable power. Yet recently, many states have undertaken deliberate steps to weaken those monopolies and to allow competition in energy markets based on the premise that competition works to reduce the ultimate cost to end-consumers. 
CPS is the largest municipally-owned power provider in the United States and is one of more than 2,000 such providers Nationwide (Peltier, 2011). It is the exclusive distribution supplier of electricity and gas within its certified service territory, a 1,566-square-mile area including all of Bexar County and portions of six other counties: Atascosa, Bandera, Comal, Guadalupe, Medina, Wilson, and Kendall. Unlike many municipal energy systems, CPS not only owns all of its own transmission lines, it also generates much of the power transmitted through those lines. Its production base is robust enough to support its native customer demand and, in addition, provides the capability to provide wholesale power to a number of smaller municipal utilities in South Texas (SAEDF, 2013). Ranked as one of the best-managed and most economical Utilities in the Nation, CPS has positioned itself to meet current needs as well as future growth within its service area. The company enjoys strong financial ratings from Moody's Investors Services, Inc. (Aal), Fitch Ratings (AA+), and Standard and Poor's Rating Services (AA) (SAEDF, 2013).

In addition to 710,000 electric customers, CPS distributes natural gas to 328,000 customers within its service area. Its gas rates are among the lowest in the State and when compared to the 20 largest municipalities in the U. S., are some of the best rates available (SAEDF, 2013). CPS boasts one of the best, most reliable gas distribution systems in the Country, offering an ample gas supply, with sufficient capacity to provide natural gas to new industrial development and growth in the San Antonio area. With 88 miles of gas transmission mainlines and nearly 4,400 miles of gas distribution lines, CPS has enough capacity to supply its existing customer base with spare capacity to meet future growth (SAEDF, 2013). Since the energy embargo of the 1970's, CPS has applied the principle of diversity to almost every aspect of its business and its gas service is no exception (Pruske, 2004). Utilizing a pool of 60 gas providers, CPS is able to maintain competitive prices and meet growing demand.

In order to manage and service such a robust and rugged service area, CPS has invested in a state-of-the-art communications system which not only enhances internal operations, but also allows CPS to effectively communicate with their customers. The system consists of a fiber optic network and wireless technology, which offers limitless possibilities in electronic information transfer. More than 500 miles of fiber optic cable makes up the backbone of the communications system. Wireless technology also plays a vital role in the CPS communication system. Currently, CPS owns more than 60 radio towers. The towers, in conjunction with CPS's continuous automation of field devices in substations and in the electric distribution system, increase the reliability and efficiency of electric service (CPS, 2013a). CPS continues the implementation of new state-of-the-art system control and data acquisition (SCADA) systems for both electric transmission and distribution systems. Implementation of a new gas SCADA began in 2003 and as they fully realize implementation these systems will provide CPS with advanced capabilities for managing the safe and reliable delivery of energy to its customers (CPS, 2013a).

As a progressive, forward-thinking organization, CPS uses clean energy harvested from wind, solar, and landfill gas to power San Antonio with $21^{\text {st }}$ Century energy options. CPS is capitalizing on its aggressive clean energy initiatives and energy efficiency programs to meet their goal of achieving 1,500 megawatts (MW) of renewable energy power, or $20 \%$ of total generation capacity, by 2020 . To encourage the consumption and development of renewable energy and energy efficiency, CPS offers a variety of incentives and programs to both commercial and residential customers.

With an eye toward improving energy efficiency for the many business concerns in the service area, CPS offers rebates for heating \& cooling equipment, reflective roof products, commercial lighting, premium efficiency motors, innovative technologies, solar photovoltaic and incentives for new commercial construction and demand response (CPS, 2013a).

CPS is also harvesting solar power through purchase agreements in place for over $40 \mathrm{MW}$ of solar power. Recently, the Blue Wing Solar Farm came online generating $14 \mathrm{MW}$ of solar power, and another $30 \mathrm{MW}$ is scheduled to come into the CPS system from a Sun Edison project under development.

In addition to solar, CPS has invested in wind-generated electricity through its Windtricity Program. In 2002, the company became a State leader in renewable energy through acquisition of the entire output of the Desert Sky Wind Farm in West Texas (Pruske, 2004). CPS currently acquires 859 MW of wind-generated electricity. According to the Department of Energy, Texas ranks first in the Nation in wind-generated electricity and CPS is the 
largest municipal purchaser of wind energy in the United States (CPS, 2013a). The Company has clearly made a commitment to maximizing its utilization of renewable energy sources.

\section{HISTORICAL PERSPECTIVE}

San Antonio entered a new era in 1860 with the introduction of gas lamps to illuminate its nightlife and less than a decade later, electricity and electric lighting began to replace gas and gas lamps. Modernization in San Antonio in the 1880s was, much like the rest of the Country, nothing short of explosive. During the decade, civic government, utilities, street paving and maintenance, water supply, telephones, hospitals, and a power plant were all established or planned. That power plant served the City well and was the beginnings of what would ultimately become City Public Services, known today as CPS Energy (Fehrenbach, 2013).

By 1917, the San Antonio Public Service Company (SAPSCo), under the ownership of the American Light and Traction Company, was the sole provider of gas and electricity throughout the City. SAPSCo ran the City's power plants, gas network, and streetcar lines throughout the 1920's and 1930's. By the early 1940's, antitrust laws finally forced SAPSCo' parent company, the American Light and Traction Company, to sell many of its utility holdings across the Country. SAPSCo became one of the companies up for sale. The City purchased SAPSCo for \$34 million in 1942 and immediately sold the company's public transportation division leaving just the electric and gas utility divisions. After the sale, what was left of the SAPSCo became the City Public Service Board of San Antonio (CPS, 2013b).

By the late 1940 's, commercial and residential customers began installing air conditioning systems and the demand for electricity grew significantly. As the summers grew hotter, and the population expanded, demand grew larger and in response, CPS built its first new power plant since the days of SAPSCo, the Leon Creek plant. Company revenues broke $\$ 1$ million the following year which enabled the City to refinance the bonds with which it had purchased CPS (CPS, 2013b). By 1954, demand once again threatened supply and CPS built its second new power plant, completing the project that same year. In lieu of paying taxes, CPS began returning a larger portion of its earnings directly to the City and by 1960 was contributing $14 \%$ of its annual revenues to the City. Today, CPS's contribution provides more than $25 \%$ of the City's annual budget and in 2012, returned approximately $\$ 290$ million to the City, accounting for $31 \%$ of City revenues, which was more than property taxes or any other source of City revenue. In fact, since 1942 CPS has provided $\$ 4.9$ billion in revenue to the City of San Antonio (CPS, 2013b).

Some of CPS's more notable milestones include (CPS, 2013b):

- Installed the downtown areas streetlight system, a $\$ 750,000$ project involving 640 miles of cable.

- $\quad$ Opened the V.H. Braunig power plant in 1966 utilizing treated wastewater instead of drinking water from the aquifer to cool its boilers.

- Donated $\$ 1.2$ million in engineering for HemisFair '68, the World's Fair exposition, contributing to the Tower of the Americas and the Institute for Texan Cultures.

- $\quad$ Constructed Calaveras Lake which became the site of many future power plants, and provided residents of the area a popular fishing and picnic site.

- $\quad$ Three years before passage of the Civil Rights Act, CPS launched a diversity program to find and recruit gifted graduates from colleges with minority enrollment.

- In 1972, opened its first gas-fired power plant, the O.W. Sommers power plant. The following year, OPEC's oil embargo and the ensuing energy crisis forced CPS to redesign future plants to run on less expensive coal.

- In 1977, in response to rising prices and a necessary raise in rates (the first in Company history) CPS stepped up conservation efforts at its plants and among its customers, working with other Texas utilities on a jointly-owned nuclear power project (today known as the South Texas Project), and opened the J.T. Deely coal-fired plant.

- In 1980, the Company took steps to diversify its energy sources and shore up its distribution network opening the Hill Country switching station and the North Gate Pipeline, which, for the first time allowed more than one competing supplier access to CPS markets. 
- In 1988, San Antonio reaped the rewards of CPS involvement in the South Texas Project and began receiving safe, clean, and efficient nuclear energy from the plant.

- The 1990's saw increases in demand and once again CPS responded with the J.K. Spruce coal-fired plant which opened in 1992. The plant was built with more than $\$ 100$ million worth of environmental regulation systems.

- In 1992, CPS increased environmental awareness and added continuous emissions monitoring systems to all of the companies operating plants.

CPS has an annual operating budget which includes revenues from sales of gas and electric services of just over $\$ 2.3$ billion. After subtraction of its liabilities, including contributions directly to San Antonio's operating budget, CPS ended its last fiscal year with $\$ 29.3$ million in net income and increased its net fund assets by $\$ 21.3$ million. CPS is the sixth largest employer in the City employing over 3,600 employees and its wage and benefits scale is set to compensate employees to the $50^{\text {th }}$ percentile of competitive market rates (CPS, 2013a). With a mean annual salary of $\$ 76,000$, CPS has the distinction of being one of the highest paying employers in the City (BLS, 2013).

\section{FINANCIAL INTEGRITY}

Maintaining a strong financial position and having the liquidity to cover its operating costs have been and continue to be at the forefront of CPS's focus. The Company's disciplined use of revenue to cover Company commitments results in consistent returns to the City and a cash position which allows the Company to cover its capital commitments. CPS is committed to reducing its debt to lower than $60 \%$ by 2020 and is working to ensure its large capital programs are adequately funded so that the Company can meet its stated objective of moving from traditional energy production to sustainable operations (Sustainability, 2012). The use of Company revenues is prioritized to first cover operating and maintenance, including fuel, followed by debt servicing, repair and replacement cash contributions, payments to the City, and lastly, the remaining revenues are added to repair and replacement contributions (CPS, 2013a).

\section{Debt Servicing}

CPS has exceeded its goal of $1.5 \mathrm{X}$ all-in coverage ratio for debt servicing (all debts) in each of the last five years and continues to maintain strong liquidity which indicates the ability to cover a robust and expensive capital improvements program (Fitch, 2012). With unrestricted cash of $\$ 814$ million, including its repair and replacement fund, the Utility has roughly 243 days of cash on hand. While debt levels are moderately high and continue to increase, CPS continues to exhibit its ability to service this level of debt (Sustainability, 2013).

With over $\$ 3$ billion in capital improvements projected over the next five years, CPS must maintain its ability to cover its normal operations while investing in a future that will emphasize use of renewable energy sources. Liquidity is key to CPS's ability to continue to make improvements to its generation and distribution channels. Not only does CPS maintain an impressive cash reserve, it has special instruments such as an affordable note payable program, operated by Frost Bank, which functions as a line-of-credit. Success in maintaining its financial integrity is evident in the rates it charges for electricity, rates which are lower than in many other Texas cities such as Houston, Dallas, and Corpus Christi. Financial integrity also allows the Company to focus on its external stakeholders and has led to CPS maintaining one of the best credit ratings among municipally owned utilities nationwide (Sustainability, 2012). 


\section{COSTS CONTROLS}

At a time when U.S. households are paying record prices for the electricity they consume, CPS has been able to keep its prices consistent and relatively low. As prices for fuel, maintenance, and generating power increase, so do the rates that companies must charge their customers. CPS has experienced much of the same upward pressure on the cost of doing business as have others in this industry. However, unlike many others in the industry, CPS has been largely effective at keeping the cost of its electricity and gas under control thanks in large part to a business model that values diversification, seeks maximum returns to the City as well as its citizens, and places demand management at the forefront of planning. In fact, CPS has continually beat the National average cost per kilowatt hour (KWH) which according to a January 2012 report released by the U.S. Energy Information Administration was 9.83 cents/kwh in 2010 (EIA, 2013). The Texas average per $\mathrm{kWh}$ in 2010 was 9.34 cents/kwh and CPS customers paid on average for the year 9.1 cents/kwh (EIA, 2013). In 2011 the savings were even more substantial. According to the San Antonio Express-News citing the Utility's own statistics and a report by USA Today, the National average cost per kwh was 11.54 cents/kwh, the Texas average rose to 11.6 cents/kwh, however CPS charged its customers just 9.3 cents/kwh (Hamilton, 2013a).

\section{Diversification and Low Costs}

CPS has kept costs low through a two-pronged strategy of diversification and demand management. In the 1970 's, CPS was largely reliant on natural gas to fuel its power plants. However, the 1973 Arab oil embargo forced some drastic changes at CPS. As the price of natural gas began to rise steeply, diversification became the Company's primary strategy and more than four decades later, diversification remains a key to the Utility's success and a primary business strategy for CPS (Pruske, 2004). In response to rising prices in 1973 and beyond, CPS began retrofitting gas-fired units to burn varying grades of fuel oil and built an extensive oil storage complex to enable the Utility to buy in bulk and store the excess for future need as price was favorable (Pruske, 2004). Following the move to fuel oil, CPS redesigned proposed new gas-fired generating stations to coal, purchased railcars to transport lowsulfur coal from Wyoming to San Antonio, and added the infrastructure necessary to handle coal at the Calaveras Lake plant site. The move away from natural gas was swift, the first of two 405 megawatt (MW) coal-fired units went on-line in 1977, followed by the second unit a year later (Pruske, 2004). These decisive moves enabled CPS to mitigate the rising cost of natural gas and ensured the Utility would not be held hostage to the volatility of international energy markets as its mainstay source of fuel would be domestic coal, a fact which is true to this day.

To further diversify, CPS joined the South Texas Project (STP) nuclear power plant as a $28 \%$ participant. STP's twin 1250 MW units near Bay City Texas offers a stable, readily available, and cost effective source of energy serving to further diminish the Utility's reliance on international fuel markets which had been the source of so much concern throughout the 1970's and 1980's (Pruske, 2004). CPS customers continue to benefit from STP's inexpensive and abundant energy and the electricity purchased from the plant continues to be the Utility's least expensive source of fuel (Pruske, 2004).

\section{Renewables}

In 2003, CPS initiated its Strategic Energy Plan which called for 15\% of energy consumed in San Antonio to be supplied by renewable energy sources by the year 2020. In 2009, it increased that goal to $20 \%$, which resulted in an increased emphasis on diversifying sources of fuel. The drive for diversification has consistently increased as the Utility has moved towards renewable energy sources through its Windtricity and solar energy programs. Windtricity, as the name suggests, is the purchase of wind power from wind turbines located largely along the gulf coast and in the western portion of the State. In 2002, CPS became the State leader in renewable energy when it acquired the entire output of the Desert Sky Wind Farm (Pruske, 2004). The 160 MW output at Desert Sky was equal to approximately four percent of peak demand in 2002 and allowed CPS to offer clean energy at an affordable price. Today, electricity generated from the West Texas plains and Texas coastal wind farms total nearly 1,060 MW of electricity making CPS the largest publicly owned purchaser of wind power in the Country and providing enough clean energy to service approximately 240,000 homes (CPS, 2013a). 
Alongside its aggressive move into wind energy, CPS has a number of Company-owned or contracted solar projects to augment its renewable energy portfolio. Solar energy contributes nearly $45 \mathrm{MW}$ of power with another $400 \mathrm{MW}$ under contract. That total will amount to $5.5 \%$ of current peak capacity and is scheduled to grow as the Utility seeks to increase its renewable energy footprint (CPS, 2013a). The $400 \mathrm{MW}$ project CPS inked with OCI Solar Power promises a partnership between CPS, the City of San Antonio, and OCI Solar Power which is the first of its kind in the Nation and when fully implemented will catapult Texas into the top five U.S. solar producing states. The energy produced as a result of this agreement will power nearly 70,000 households and will amount to about $10 \%$ of supply (Solar, 2012). In addition to the clean source of energy, the deal is expected to result in an estimated \$100 million high-tech manufacturing operation in south San Antonio which will result in 800 highpaying professional and technical jobs for the City (Solar, 2012).

Combined with CPS's bio-gas plants which harvest and use gas from local landfills to power generation plants, it is easy to see just how diverse CPS has become in terms of its sources of electric generating fuel sources (see Table 1). All told, CPS is capable of a total generating capacity of just over 8,000 MW at peak demand from its mix of fossil, nuclear, wind, solar and bio-gas plants and the Utility is well positioned to meet San Antonio's continued robust growth in its residential, commercial, and industrial energy customer base (CPS, 2013a). CPS continues to demonstrate an ability to quickly adjust and adapt as the price for fuel changes and plans the addition of another natural gas plant to replace its oldest coal fired plant. While natural gas has been volatile in terms of price, recent improvements in how natural gas is mined, which has resulted in a more robust and stable domestic supply, suggests that natural gas prices will remain stable for the foreseeable future.

Table 1. Generation Sources and Capacity at CPS Energy

\begin{tabular}{lc}
\hline \multicolumn{2}{c}{ Power Generation } \\
\hline Coal (Spruce 1 \& 2 and Deely 1 \& 2): & $2,184 \mathrm{MW}$ \\
Natural Gas (AVR, Sommers, Braunig, Rio Nogales): & $3,001 \mathrm{MW}$ \\
Nuclear (STP 1 \& 2): & $1,080 \mathrm{MW}$ \\
Peaking Units (Leon Creek, Tuttle, Braunig Peakers) & $631 \mathrm{MW}$ \\
Capacity: & $\mathbf{6 , 8 9 6 ~ M W}$ \\
\hline \multicolumn{1}{c}{ Renewable Generation (in Commercial Operation) } \\
\hline Wind (8 projects) & $1,059.1 \mathrm{MW}$ \\
Solar (4 solar farms; 400 MW more under contract) & $44.3 \mathrm{MW}$ \\
Landfill Gas (4 MW more under contract) & $9.6 \mathrm{MW}$ \\
Current Capacity: & $\mathbf{1 , 1 1 3 ~ M W ~}$ \\
Total Capacity & $\mathbf{8 , 0 0 9} \mathbf{M W}$ \\
\hline
\end{tabular}

Source: CPS Energy, 2012.

\section{Demand Side Management}

While diversification has played a key role in CPS's ability to keep costs low and to pass along savings to its customers, they are not simply relying on multiple fuel sources alone to keep costs low. The cost of added generation capacity as demand rises is often the largest driver of increased cost for a utility. For CPS, the latest addition to its generation capability was a state-of-the-art, clean-burning coal plant which cost just over $\$ 1$ billion to build (CPS, 2013a). In order to minimize future construction costs, CPS embarked on an ambitious program to reduce future demand, thereby reducing the need for increased generating capacity. Initially, CPS committed $\$ 96$ million toward an energy efficiency program with a goal of reducing peak demand by $40 \%$ or $115 \mathrm{MW}$ by 2011 and $425 \mathrm{MW}$ of electrical capacity by 2020. More recently, through its Save for Tomorrow Energy Plan (STEP), CPS is actively seeking a reduction in the growth of demand for electricity of 771 megawatts (MW) by the year 2020, roughly the output of a large power plant (CPS, 2013a).

To achieve this goal, the Utility has committed millions of dollars to pay incentives and provide rebates to consumers to reduce demand. The program encourages residents to purchase energy-efficient appliances, improve heating, ventilation and air conditions systems and insulation, and increase the use of programmable thermostats to realize immediate savings in individual energy use (CPS, 2013a). The program consists of various residential and commercial/industrial programs such as their Smart Thermostat (Peak Saver), Home Area Network (Home Manager), and Commercial \& Industrial Response (C\&I). According to the City, the total cost of the program to 
CPS will be approximately $\$ 849$ million with annual costs ranging from $\$ 12.3$ million to over $\$ 77$ million (Sustainability, 2013). Smart Thermostat (Peak Saver) is a program offering free programmable thermostats to CPS customers. Once installed, homeowners can agree to allow CPS to cycle off their heating and air conditioning during peak demand periods. Through its Home Area Network program, that capability expands to include other highenergy use appliances such as water heaters, washers, and driers. Additionally, homeowners have expanded remote access to control energy usage and the ability to monitor and change home energy usage by the hour. CPS' C\&I program offers incentives to industrial and commercial ventures to reduce energy use.

CPS Energy Savers is also offering significant incentives for commercial customers. By joining CPS Energy Savers, business customers qualify for an additional $10 \%$ on top of the existing utility rebates. In addition to these savings is the "retro-commissioning" program, which is a systematic, documented process that identifies lowcost operational and maintenance improvements for existing buildings. CPS Energy Savers pays $75 \%$ of the cost of the study to identify existing rebates for improvements made. Together, these three programs form the nucleus of CPS's Vision 2020, approved by the City in 2009 (CPS, 2013a). To date, the various programs have resulted in reduced usage of $273 \mathrm{MW}$.

\section{CPS E-Commerce Aimed at Reduced Natural Gas Costs}

While the bulk of CPS expenditures and revenues are tied to its electricity generation and distribution, it is important to remember that CPS is also the provider of gas to many of its customers. Just as it has with its electric division, diversification has enabled CPS has continued to deliver consistently low rates and reliable service to its gas customers. In addition to finding additional sources of gas and increasing the number of ways to bring gas supply into the CPS system, they initiated an e-commerce program and signed agreements with Enporion, a leading provider of advanced and highly efficient sourcing and procurement services for the energy utility industry. The initial agreement was for $\$ 5$ million and was CPS's initial foray into the world of e-commerce. The agreement with Enporion was a significant step as CPS continued to provide cost-effective energy rates by diminishing supply chain costs and it represented a first-of-its-kind agreement between a municipally-owned utility and an independent sourcing and procurement service company (CPS San Antonio, 2004). This partnership with Enporion has resulted in millions of dollars in savings to the Utility and those savings are passed directly on to CPS customers.

\section{RELIABILITY}

A 2011 Associated Press analysis of utility spending and reliability Nationwide found that spending on maintaining electric distribution grids has increased year to year. It also points to outage rates that are stable year to year. However, according to the study, while outages happen with the same frequency, when they do occur now, it takes longer to restore service than at any time in history (Fahey, 2013). At the same time that reliability trends downward, spending on maintenance and improvements to distribution systems continues to trend upward suggesting that the extra money from electric customers is not being spent wisely or that the amount being spent on upgrades to the system is not enough to keep up with the natural aging of equipment and increased pressures on the system by a growing customer base (Fahey, 2013). These diminishing returns on investment reflect an aging distribution grid, increases in day-to-day weather extremes, and increased major storm activity which results in damages to above ground grid components such as wires, poles, and transformers (Fahey, 2013). And while the numbers detailing the trends are not dramatic, they are troubling. For 2011, the per-customer cost of maintenance was $\$ 232$, up from $\$ 163$ less than a decade earlier, and an increase of $42 \%$. At the same time, the number of outages remained essentially unchanged while the length of outages increased by $15 \%$ (electrical customers experienced an average outage period of 112 minutes). These numbers do not take into account major outages such as those experienced in the wake of super storm Sandy early in 2013, which left large parts of New York and New Jersey without power for weeks (Fahey, 2013).

CPS has bucked this trend and its customers experienced an average of only 59 minutes without service in 2011, ranking the company in the top five in terms of average outage minutes in a National survey (Hamilton, 2013b). While no utility can promise zero outages, CPS has committed itself to improvements to infrastructure and maintenance capability in an effort to improve reliability. 


\section{Balancing Maintenance and Construction}

Improvements in reliability at CPS are due in part to an innovative and proactive approach to maintenance and a program of improved infrastructure, which places CPS at the head of the class in its approach to service and reliability. CPS initiated a pole replacement program intended to fill two needs for the City, lower maintenance costs due to reduced reliance on aboveground poles and lines and, city beautification. In addition to savings associated with lower maintenance costs of underground transmission lines, CPS' innovative undergrounding scheme provides the benefit of removing aboveground wires and poles from scenic, historic districts and public spaces (Scenic America, 2013). With a National average range of $\$ 500,000$ to $\$ 3$ million per mile, the biggest challenge to undergrounding wires for any city is the cost for utility burial (Schiller, 2001). Unlike other undergrounding programs across the Nation, the CPS initiative costs consumers nothing, and gives the City complete political control over the program. CPS returns one percent of retail electric sales revenue to the City to pay for utility burial and relocation. San Antonio City management is then responsible for determining how best to spend the money (Scenic America, 2013). We will discuss the many intangible contributions that CPS makes to the City in a subsequent section, but for now, it is important to note CPS' emphasis on training and maintenance, which are at the heart of its reliability program. While the City of San Antonio and the CPS' customer base continue to grow, CPS linemen must maintain what is currently in service, as well as address new construction to support City growth and new customer demand. To balance the maintenance and construction demands, CPS has taken a proactive approach by double teaming when the job warrants more than one crew, and using innovative tools and equipment to expedite the job (White, 2007).

\section{Investments in Information Technologies}

When CPS entered into the $21^{\text {st }}$ century, it became obvious to organizational leaders that information technology had become an albatross for the Company. Its aging analog systems as well as a continued reliance on two-way radios for communication between maintenance crews and home-based personnel could no longer meet the needs of CPS's rapidly expanding service area. In 2006, CPS began the process of transitioning from its traditional systems to one based entirely on digital transmissions utilizing the latest technologies. The goal was to improve communication and data management resulting in improved customer service and system reliability. Upgrades to wireless technology and applications could be as simple as updating the hodge-podge of old and outdated equipment and replacing it with newer equipment. But CPS set a course of improvement intended to maximize wireless technology with an overall strategy of mobility capabilities which would grow with the Company (Scarlett \& Roark, 2008). Working closely with Motorola, CPS put in place a system which updated all aspects of its data management system to provide work crews with instant access to systems and failsafe communication which allows real-time transfer of information. The result is a system which equips all 1,500 CPS vehicles with the ruggedized laptops and communications equipment necessary to stay in touch and to facilitate ease in transmission of critical information. The new system resulted in reduced employee training time, digital IP-based data and ease of data transfer, and vehicle work stations which are the focal point of the mobile system and which have the added value of being much easier to maintain. These improvements, along with a well thought out maintenance and construction plan have allowed CPS to remain a leader in terms of reliability and have cemented the relationship the Utility enjoys with its customers.

\section{ENVIRONMENTAL LEADERSHIP}

CPS, through a number of programs with sustainable energy and resource conservation in mind, continues to provide benefits to the community and the environment. For instance, in 2010, CPS committed to partner in the Texas Sustainable Energy Research Institute at the University of Texas at San Antonio for sustainable energy research. As part of the agreement, CPS has committed investments of up to $\$ 50$ million over 10 years and provided $\$ 1.8$ million in funding through 2012 (Sustainability, 2012). Investments in sustainable energy technologies provide a roadmap for future improvements and will assist the Company in achieving its goal of transitioning from fossil to renewable fuels. Current programs utilizing current capabilities provide a glimpse at how dedicated the Company is to reducing any negative impact it may have on the environment and the areas scarce natural resources. 


\section{Wastewater Reclamation}

Braunig and Calaveras Lakes, built in the late 1960s to provide cooling water for equipment at nearby power plants, offer a perfect example of the environmentally-sensitive cognition that is typical of CPS. Following a record drought in the late 1950s, and desiring to conserve Edwards Aquifer water for drinking purposes, CPS turned to treated wastewater to fill the two reservoirs distinguishing CPS as one of the first Utilities in the Nation to use treated city sewage for use in power plant cooling (CPS, 2013b).

Today, the idea continues to pay significant dividends. By using recycled wastewater in the lakes rather than fresh water, more than 45,000 acre feet of drinking water from the aquifer are conserved each year (Pack \& Brindle, 2012). In terms of gallons of water saved, the lakes have conserved over 308 billion gallons of water since they were constructed in 1967. Additionally, the lakes provide family-friendly recreation for the residents of Bexar County and offer picnic and camping areas, boat ramps, piers and shorelines for the areas fishers (CPS, 2013b). The water is safe for the lakes aquatic life and for those who enjoy the lakes for recreational purposes. The lakes warm water provides ideal conditions for various species of fish and are stocked with largemouth bass, catfish, hybridstriped bass, and red drum. Not only do the lakes utilize reclaimed waste water from the City, the water used in the cooling process at the nearby power plants is recycled and returned to the lakes, further enhancing the benefits by additionally reducing the draw on San Antonio's lone source of water, the Edwards Aquifer.

\section{Toward a Green San Antonio}

From 1985 through 2001, American Forests conducted an Urban Ecosystem Analysis of the greater San Antonio area. The study was used to determine landscape changes over time and to assess the impact those changes have had on air and water quality, as well as energy consumption rates. According to the study, San Antonio has lost $39 \%$ of its heavy tree cover, which is the equivalent of 45,000 acres of heavy tree canopy. The environmental impact is a loss of air pollution abatement to the tune of $\$ 9$ million per year and a total of $\$ 146$ million in additional storm water management costs. The loss of shade in the City has also resulted in an increase of over $\$ 1$ million in additional cooling costs each summer which places additional demands on the energy distribution grid (Kollin, 2013).

Based on the outcomes and recommendations in the study, CPS formed the Alamo Forest Partnership and allocated necessary resources to restore the City's tree canopy. Collaborating with the Texas Forest Service, City of San Antonio, University of Texas at San Antonio, Alamo Area Council of Governments, San Antonio Water System, Texas Parks and Wildlife, U.S. Department of Defense, U.S. National Park Service, local nonprofits San Antonio Forest and San Antonio Trees, Bexar Audubon, and Neighborhood Resource Center, CPS leads the tree planting effort (Kollin, 2013). The City Council passed a new City tree preservation ordinance and since 2001, CPS has given away more than 33,000 trees. In 2009 alone, CPS distributed 4,707 trees through its tree donation partnership programs with Habitat for Humanity, Real Estate Council's Green Team Challenge, San Antonio's Neighborhood Sweeps program, and public events like Earth Day at Woodlawn Park and LiveGreen Fest (Sustainability, 2012).

\section{COMMUNITY CONTRIBUTIONS}

If CPS were to concentrate solely on low cost and reliability, most consumers in the service area would likely be satisfied. And while emphasizing costs reduction and capability improvements, resulting in some of the highest levels of reliability in the Nation are certainly commendable, what elevates CPS to a higher level is its view of and service to the community. By consistently providing value-added contributions to the City through its various community improvement programs, CPS exemplifies excellent corporate social responsibility. Since 1998, CPS has published biennial environmental reports covering a range of topics from air quality to water management. In 2006, CPS began collecting data concerning its corporate obligations to its key stakeholders and in 2010, published its first Corporate Sustainability Report. The report lays out CPS' vision for the future and begins with the statement that in order to continue its great tradition of economic viability, CPS "must look into the future rather than admiring [its] past. The challenges of aging infrastructure and increasing environmental concerns, like climate change, have the potential to significantly increase the costs of energy from fossil fuel generation. Multiple indicators reveal that the 
current path is not sustainable" (Sustainability, 2012). They define sustainability as "meeting the needs of the present without compromising the ability of future generations to meet their own needs" (Sustainability, 2012).

As a municipally-owned Utility, CPS is accountable to a large and diverse group of stakeholders, including: end-consumers, City of San Antonio, bondholders, suppliers, San Antonio Water System, Bexar County, Electric Reliability Council of Texas, Public Utility Commission of Texas, the Texas Legislature, and even the Federal government. It is no coincidence that CPS lists its customers first when speaking of its external stakeholders. CPS' commitment to customer concerns has been a hallmark of the Company's values from its inception. In order to ensure that customers concerns are effectively and efficiently addressed, CPS has initiated a number of programs designed to provide channels for gathering feedback. Examples of these initiatives are: Citizens Advisory Committee, public forums such as the Energy Summits, ad hoc community representative groups, meetings with chambers of commerce, Economic Development Foundation, Alamo Area Council of Governments, San Antonio Manufacturers Association, and neighborhood associations, customer satisfaction surveys and studies, breakfast meetings with community leaders, and periodic meetings with Express-News editorial board. All of these efforts are vectored toward customer satisfaction and providing CPS with a keen understanding of the needs of its customers.

Through its Project Warm (Winter Assistance Relief Mobilization) and Project Reap (Residential Energy Assistance Partnership) initiatives, CPS assists disadvantaged, elderly, disabled, and low-income families with small children who are struggling to pay their natural gas and electric bills (Human Services, 2013).

\section{CPS Energy Volunteers in Public Service (VIPS)}

Since 1989, through Volunteers in Public Service (VIPS), CPS's community service program, hundreds of CPS employees, retirees, and their families have provided thousands of volunteer hours each year to local charities, nonprofit organizations, and other community projects. The people who work at CPS best illustrate CPS's commitment to community relationships and their collective desire to be a truly invested partner with the community.

VIPS ran an internal four-week Project Cool Fan Drive, raising employee donations of over $\$ 24,000$ with which they were able to deliver 2,030 box fans to the Project Cool campaign. Over 13 years, Project Cool has distributed 46,300 fans to local senior citizens. CPS also provides all Project Cool participants with bilingual information on how to weatherize their homes (Sustainability, 2012). Programs supported by VIPS volunteers include holiday toy collection and party for underprivileged children, delivery of hot meals to the City's elderly and needy, school supply collection and distribution, and children with special-needs fishing events at Calaveras Lake Park. All told, VIPS has contributed more than 25,000 hours of community service.

In 2011 alone, CPS employees completed more than 8,000 community service hours and donated more than $\$ 40,000$ for various community projects. The money is in addition to the more than $\$ 880,000$ that employees and retirees gave to the United Way that same year. In 2011, employees gave of their time as well and participated in over 20 charitable community events, including the building of walking paths, park beautification and planting of trees. As a result, in 2012 The United Way recognized CPS for its commitment to community and awarded the company its Volunteer of the Year Award in the Corporate Large Business category (Aldridge, 2012).

\section{CONCLUSIONS}

CPS serves as an excellent example of an organization, operating as a natural monopoly, which proactively chooses to care for the environment, satisfy the needs of a diverse community, value its employees, and deal equitability with suppliers, all while maximizing returns to its stakeholders. CPS demonstrates how social responsibility and value/profit maximization are not necessarily mutually exclusive. CPS' view of debt, costs, and cash have positioned it favorably to borrow, when necessary, at desirable rates and have resulted in maximum dollars returned to the City of San Antonio (as much as $25 \%$ of the city's budget) thereby reducing the tax burden on its citizens. 
CPS has been a driving force in environmental conservation and as a direct result of many of their initiatives, dwindling natural resources are carefully guarded to ensure their availability for future generations. Its many programs that minimize the impact of its business on the environment in order to preserve scarce and dwindling natural resources entrusted to its care evidence proof of CPS' wise resource stewardship. CPS has a consistent, proven record of best-practices that should be considered by other utilities seeking to develop a sustainable competitive advantage. The CPS business model is responsive to its stakeholders, returns maximum value to its owner, and provides a case study for other cities to study and adopt from.

\section{DISCUSSION QUESTIONS}

1. What are the components of CPS's value chain?

2. Which of the generic competitive strategies most closely approximates the approach that CPS is employing? What might it be if CPS were not operating in a natural monopoly setting?

3. How strong are the competitive forces confronting CPS? Provide a five-forces analysis to support your response.

4. What does a SWOT analysis reveal about the overall attractiveness of CPS's situation and future prospects?

5. If you were a senior executive at CPS Energy, what would your major priorities be?

\section{AUTHOR INFORMATION}

Steven S. Ferrell is Program Manager for the Defense Institute for Medical Operations where he is responsible for the planning and execution of medical training missions to partner nations around the world. Steve received his B.S. in Business Administration from Wayland Baptist University and his M.S. in Business Administration from the University of the Incarnate Word. Steve is a Veteran of the U.S. Air Force, having retired in 2007 after 23 years of service.

Dr. Ryan Lunsford is Associate Professor of Business and Chair of the Master of Science in Business Administration at the University of the Incarnate Word in San Antonio, Texas. Professor Lunsford serves on the University Planning Commission and Graduate Council and teaches a variety of undergraduate, graduate, and executive courses both online and face-to-face.

\section{Additional Information}

This case study is targeted primarily towards upper-level undergraduate courses, particularly capstone and management courses.

\section{REFERENCES}

Aldridge, J. (2012, June 29). CPS Energy named United Way corporate volunteer of the year. Retrieved from San Antonio Business Journal: http://www.bizjournals.com/sanantonio/news/2012/06/29/cps-energy-namedunited-way-corporate.html

APPA. (2013, May 7). Public Power: Shining a light on public service. Retrieved from American Public Power Association: http://www.publicpower.org/aboutpublic/index.cfm?ItemNumber=429

Audin, L. (2005). Making Waves Makes Money. Engineered Systems, 22, 20-24.

BLS (2013, May). May 2012 Metropolitan and Nonmetropolitan Area Occupational Employment and Wage Estimates. Retrieved from Bureau of Labor Statistics: http://www.bls.gov/oes/current/oes_41700.htm\#210000

CPS (2013a, May 11). San Antonios Energy Future and You: Learn more about our strategic energy plan. Retrieved from CPS Energy: http://www.cpsenergy.com/Residential/Information_Library/Strategic_Energy_Plan_faq.asp

CPS (2013b, May 10). Who We Are: The History of CPS Energy. Retrieved from CPS Energy: http://www.cpsenergy.com/About_CPS_Energy/Who_We_Are/History/History_of_CPS_Energy.asp

CPS (2012). 2011/2012 Annual Report. Retrieved from CPS Energy:

https://cpsenergy.com/content/dam/corporate/en/Documents/Finance/2012_CPSEnergy_Annual_Report.pd 
CPS San Antonio signs agreement for Enporion Dynamic Commerce Service. (2004, June 10). Retrieved from Business Wire: http://search.proquest.comdocview/445656356?accountid+7139

EIA (2013, May). State Electricity Profiles 2010. Retrieved from Energy Information Agency: http://www.eia.gov/electricity/state/pdf/sep2010.pdf

Fahey, J. (2013, May 15). US power grid costs rise, but service slips. Retrieved from Associated Press: http://bigstory.ap.org/article/us-power-grid-costs-rise-service-slips

Fehrenbach, T. R. (2013, May 07). "SAN ANTONIO, TX," Handbook of Texas Online. Retrieved from Texas State Historical Association: http://www.tshaonline.org/handbook/online/articles/hds02

Fitch (2012). Fitch rates san antonio city public service's (TX) electric \& gas system revs 'AA+'; outlook stable. Entertainment Close - Up. Retrieved from http://search.proquest.com/docview/940972690?accountid=7139

Giles, E. F., \& Brown, K. L. (2013). UDI Directory of Electrical Power Producers and Distributors. New York: The McGraw-Hill Companies.

Hamilton, T. (2013a, May). CPS customers pay 20\% less than state average. Retrieved from My SA: http://www.mysanantonio.com/news/energy/article/CPS-customers-pay-less-than-state-national2421241.php

Hamilton, T. I. (2013b, March 15). Reliable electric grid remains a focus of CPS Energy. Retrieved from CPS Energized: http://blog.cpsenergy.com/reliable-electrical-grid-cps-energy/

Human Services. (2013, June 10). Emergency Services. Retrieved from City of San Antonio: Department of Human Services: http://www.sanantonio.gov/comminit/EmergencyCenterWorkingFamiliesRequirements.aspx

Kollin, C. (2013). San Antonio: Ripples of change. American Forests, 7-10. Retrieved from $\mathrm{http}: / /$ search.proquest.com/docview/198679389?accountid=7139

McKinzie, Clint. (2013, January 4). San Antonio, Texas, Goes Big on Efficiency to Help Shrink Utility Bills. Retrieved from U.S. Department of Energy - Energy Efficiency and Renewable Energy: https://www1.eere.energy.gov/buildings/betterbuildings/neighborhoods/printable_versions/san_antonio_pro file.html

Pack, L., \& Brindle, R. (2012, September 12). Municipal Wastewater Reuse by Electric Utilities: Best Practices and Future Directions. Retrieved from Increasing the Reuse of Municipal Wastewater at Power Plants: $\mathrm{http} / /$ nexightgroup.com/projects/increasing-the-reuse-of-municipal-wastewater-at-power-plants/

Peltier, R. (2011). "J.K. Spruce 2, Calaveras Power Station, San Antonio,. Power, 34-35. Retrieved from Peltier, Robert. "J.K. Spruce 2, Calaveras Power Station, San Antonio,.

Pruske, J. (2004, August). Diversification: Big Word Big Results for San Antonio. Electric Light \& Power, 45. Retrieved from www.elp.com

SAEDF (2013, May 11). Retrieved from San Antonio Economic Development Foundation: http://www.sanantonioedf.com/business-profile/utilities/electric-a-gas

Scarlett, J., \& Roark, C. (2008, November). CPS Energy Creates an Energized Mobility Strategy. Retrieved from Utility Automation Engineering: www.utility-automation.com

Schiller, T. (2001). Rewiring the system: The changing structure of the electric power industry. Business Review Federal Reserve Bank of Philadelphia, 26-33. Retrieved from http://search.proquest.com/docview/231381238?accountid=7139

Solar, C. E. (2012, July 23). CPS energy and OCI solar power launch largest municipally owned mega solar project. PR Newswire. Retrieved April 18, 2013, from $\mathrm{http}: / /$ search.proquest.com/docview/1027445428?accountid=7139

Sustainability (2012). Corporate Sustainability Report. San Antonio: CPS Energy.

Sustainability (2013, May). Save for Tomorrow Energy Plan. Retrieved from City of San Antonio Office of Sustainability: http://www.sanantonio.gov/sustainability/Environment/SaveForTomorow.aspx

White, M. (2007). Balancing maintenance and construction. Transmission \& Distribution World, 59(11), 364F,64H,64I. Retrieved from Transmission \& Distribution World: http://search.proquest.com/docview/211152029?accountid=7139

Zaja, J. (2010). It's not the economy, stupid: It's the customers. Retrieved from SNL Energy Power Daily: http://search.proquest.com/docview/867847843? accountid=7139 